\title{
Analysis of Seasonal Precipitation, Potential Evapotranspiration, Aridity, Future Precipitation Anomaly and Major Crops at District Level of India
}

\author{
Laxmi Goparaju $^{1}$ (D) Firoz Ahmad ${ }^{1}$ (D)
}

Received: 26 February 2019 / Accepted: 11 May 2019 / Published online: 5 June 2019

(C) The Author's 2019, corrected publication 2019

\begin{abstract}
Climate-induced risks are very significant in these days and will impact the agriculture crop production because of the change in hydro-climatic condition. Remote sensing and GIS framework provide scientific understanding in practical application systems with the sustainable solution in new climate change reality and support significantly in resilience to mitigate the future risk. The paper deals with long-term (1970-2000) monthly thematic datasets and analyzed the seasonal (kharif, rabi and zaid) pattern of precipitation, potential evapotranspiration and aridity index to scale of district level of India. Additionally, we have used the predicted (2025) monthly precipitation anomalies data (climate change scenario) to examine the seasonal precipitation pattern at the district level of India. The major agriculture crops (rice, wheat, and maize) for the year 2005 were also evaluated during those seasons. Such analysis gives better understanding and knowledge of district-wise seasonal spatial pattern at country level (India) of climate stress, crop water demand and suitably applied to make strategies/ synergic approach toward agriculture resilience. The long-term seasonal aridity index pattern analysis varies significantly throughout India during kharif, rabi and zaid seasons which were manifested by cropping pattern adopted by farmers as per land potentiality. Several districts in some of the states of India receive adequate precipitation during kharif season and manifest low aridity index in rabi and zaid season which can be recommended for rainwater conservation at the watershed level to boost the agriculture crop production. Farmer's suicide hot spot districts in the arid and semiarid regions need policy intervention to develop a concrete plan including integrated watershed management strategies with traditional ecological knowledge for long-term sustainable management for climate resilience because these districts showed significantly low aridity index value in all seasons. The remote sensing and GIS-based evaluation/results of this study in conjugation with in situ ancillary datasets will support significantly to address the climate-induced risk of farmers to achieve sustainability in food security, enhancing the livelihood, eradication of poverty and magnifying the farm household resilience.
\end{abstract}

Keywords Remote sensing/GIS · Precipitation · Potential evapotranspiration · Aridity index $\cdot$ Future climate data $\cdot$ India

Electronic supplementary material The online version of this article (https://doi.org/10.1007/s42489-019-00020-4) contains supplementary material, which is available to authorized users.

Firoz Ahmad

adfiroz@yahoo.com

Laxmi Goparaju

goparajulaxmi@yahoo.com

1 Vindhyan Ecology and Natural History Foundation,

Mirzapur, Uttar Pradesh, India 


\title{
Analyse des saisonalen Niederschlages, Evapotranspiration, Trockenheit und zukünftige Niederschlagsanomalien für Ackerfrüchte auf Bundesstaatsebene in Indien
}

\begin{abstract}
Abstrakt
Aufgrund von hydroklimatischen Änderungen im Rahmen des Klimawandels kommt es zu Risiken für die landwirtschaftliche Produktion von Nutzpflanzen. Fernerkundung und GIS können helfen nachhaltige Lösungen bzw. Anpassungsstrategien im Klimawandel für die Praxis bereitzustellen, um zukünftige Risiken zu mindern. Die Studie analysiert saisonale Muster (Kharif-, Rabi- und Zaidperiode) des Niederschlages, der Evapotranspiration und des Ariditätsindex auf Basis von monatlichen Datensätzen (1970-2000) auf der Ebene der Bundesstaaten in Indien. Zusätzlich wurden die aus Klimamodellen berechneten monatlichen Niederschlagsanomalien für 2025 in die Untersuchung einbezogen. Für 2005 wurden die Produktionsbedingungen für die wichtigsten Ackerfrüchte (Reis, Weizen und Mais) in die Untersuchung in Bezug zu saisonalen Mustern betrachtet. Die Auswertung zeigt, dass die saisonalen Trockenheitsindizes in ganz Indien während der Kharif-, Rabi- und Zaid-Saison erheblich variieren, was an den Mustern der Verteilung der Ackerbauflächen der verschiedenen Sorten gut erkennbar ist. Verschiedene Bundesstaaten bekommen während der Kharifsaison genügend Niederschlag. Es zeigt sich aber ein geringer Ariditätsindex in der Rabi- und Zaid-Saison. Daher wird empfohlen, diese Zeiträume zur Speicherung von Niederschlagswasser zu nutzen mit dem Ziel, die landwirtschaftlichen Produktion zu steigern. In den Bundesstaaten in ariden oder semiariden Regionen ist es erforderlich einen politisch gewollten, strategischen Plan zum integrierten Wasserschutzmanagement auf Einzugsgebietsebene zu entwickeln. Traditionelles, ökologisches Wissen für ein längerfristiges, nachhaltiges Management um Resilienz im Klimawandel zu erreichen, ist vor allem in den Bundesstaaten mit geringen Ariditätsindex in allen Jahreszeiten wichtig. Die GIS und Fernerkundungsergebnisse dieser Studie in Verbindung mit den In-situ-Datensätzen tragen dazu bei, das klimabedingte Risiko in der Landwirtschaft zu reduzieren, um Nachhaltigkeit in der Ernährungssicherheit zu erreichen, die Lebensqualität zu erhöhen und die Armut zu bekämpfen.
\end{abstract}

\section{Introduction}

Climate change-induced risks are extremely large these days and are a great challenge for the scientists, researchers, policymakers around the world including India. Remote sensing and GIS and recent free online crop and weather datasets provide great opportunity to understand crop productivity at a site-specific scale when integrated with seasonal climate predictions and offer tangible solutions in terms of resilience to farmers (Jimenez and Ramirez-Villegas 2018). Such a GIS framework would provide scientific understanding to attain sustainable solutions in climate change reality and mitigate future risks (Haworth et al. 2018).

Seasonal precipitation pattern impacts food grain production (Srinivasa Rao et al. 2016). The long-term trends of seasonal and monthly precipitation patterns were studied over India by several authors (Mooley and Parthasarathy 1983, 1984; Parthasarathy et al. 1994; Guhathakurta and Rajeevan 2008). The potential evapotranspiration (PET) is the amount of transfer of water to the atmosphere which significantly varies due to seasonal weather severity, thus affecting the soil moisture and nutrient availability to the vegetation (Thornthwaite 1948). Aridity is the function of precipitation, potential evapotranspiration and temperature which significantly varies with seasons. The various seasonal crop growths in terms of response vary significantly due to soil-moisture interaction (Spinoni et al. 2015) and aridity (http://www.fao.org/docrep/t0122 $\mathrm{e} / \mathrm{t} 0122 \mathrm{e} 03 . \mathrm{htm})$. Most of the Asian countries including India have three seasons such as kharif (June-October), rabi (November-February) and zaid (March-May) (Zhao and Siebert 2015), whereas the cultivated agriculture crops during these seasons vary in water supply/ demand across regions (Stefan and Zhao 2014) due to variability in precipitation and potential evapotranspiration.

The study is important because the majority of agriculture crops in India are grown seasonally (Zhao and Siebert 2015), whereas precipitation, potential evapotranspiration and aridity significantly vary across the season/region which manifests the crop's water need (Ashaolu and Iroye 2018). The selection of crop for cultivation in such environment fully depends on land potentiality and farmer's adaptive capacity (Asfaw et al. 2016). Furthermore, based on this analysis adequate strategies can be made for the conservation of seasonal rainfall/precipitation. The water which is surplus during the monsoon season can be utilized during dry months to meet the increased water supply demand and boost agricultural production significantly (Killeen and Solorzano 2008).

The aim of this paper is to evaluate the various diversified datasets such as precipitation, potential evapotranspiration, aridity index (AI) (UNESCO 1979), future (2025) precipitation anomalies data (climate change scenario) and major crops (rice, wheat and maize) for the year 2005 during the three seasons kharif, rabi and zaid and scaling 
these up to the district level of India and examine their spatial pattern in GIS domain for better conceptualization of climate-related risk. Furthermore, these strong themes give a better understanding of a paradigm approach to climate resilience practices.

\section{Materials and Methods}

\subsection{The Study Area}

The study area includes the entire land area of India (excluding islands) with geographical coordinates $6^{\circ} 44^{\prime} \mathrm{N}$ to $35^{\circ} 30^{\prime} \mathrm{N}$ latitude to $68^{\circ} 07^{\prime} \mathrm{E}$ to $97^{\circ} 25^{\prime} \mathrm{E}$ longitude. Approximately, $60 \%$ of India's total land is under agriculture practices and nearly $22 \%$ covered by forests (Ahmad et al. 2019). Agriculture-based economy in India supports the livelihood of the majority of people living in a rural area, which is in constant stress due to climate change impact.

\subsection{Data Acquisition and Processing}

The description of the data (see supplementary section) and the sources used in this study are given in Table 1.

In the present study, all raster/vector datasets were downloaded and the quality was examined for the null/missing value. The quality was found satisfactory for further processing. The monthly datasets, such as precipitation, potential evapotranspiration at the first step, were clipped by the country boundary of India, and season-wise aggregate was made. Various data were analyzed in GIS domain using ARC/GIS software (Version 10.1) using modules such as Spatial Analyst toolsets (map algebra, zonal and interpolation) at the country level of India. Furthermore, all districts were represented cartographically in terms of maps for kharif (June-October), rabi (November-February) and zaid (March-May) seasons. The AI map of kharif, rabi and zaid seasons was produced by using the ratio of respective season-wise precipitation to potential evapotranspiration. The rice-, wheat- and maize-growing areas during kharif, rabi and zaid seasons data of India were evaluated to understand the district-wise major crop scenario. The predicted (2025) monthly precipitation anomalies data were in the point vector file. The monthly precipitation surfaces were generated from the vector file by interpolation (kriging) method. The monthly precipitation surfaces were used to produce the district-wise future seasonal precipitation anomalies. The above-mentioned data were analyzed, and their spatial pattern was examined at the district level with GIS-based queries which gives better comprehension about the impact of climate change.

\section{Result and Discussion}

\subsection{Precipitation Pattern Analysis}

Agricultural activities are delicately connected to climate variability (Salinger et al. 2005; Anwar et al. 2012). The precipitation is a strong parameter in which deviation affects the land and water arrangement and linked to the agriculture output (Iizumi and Ramankutty 2015). The long-term (1970-2000) monthly precipitation data were used, and the season-wise precipitation means for kharif, rabi and zaid were evaluated at the district level of India. The evaluation of long-term precipitation during kharif season was found highest in the district of Udupi (Karnataka state) followed by West Khasi Hills (Meghalaya state), East Khasi (Meghalaya state), Dakshin Kannad (Karnataka state), Kasaragod (Kerala state) and Sindhudurg (Maharashtra state) due to active southwest monsoon rainfall activity over India (Jagannathan and Bhalme 1973). Similarly, during the rabi season mean precipitation was found highest in districts of Nagapattinam (Tamil Nadu state) followed by Thiruvarur (Tamil Nadu state), Chennai (Tamil Nadu state) and Cuddalore (Tamil Nadu state) due to returning northeast monsoon. A similar observation was found by Rajeevan et al. (2012). During the zaid season, mean precipitation was found highest in district West Khasi Hills (Meghalaya state), East Khasi Hills (Meghalaya state), Karimganj (Assam state) Bongaigaon (Assam state) and East Garo Hills (Meghalaya

Table 1 Various data and their sources used in this study

\begin{tabular}{lc}
\hline Data used & Source/references \\
\hline Mean monthly (1970-2000) precipitation data & http://worldclim.org/version2 (Fick and Hijmans 2017) \\
Mean monthly (1970-2000) Potential evapotranspiration data & $\begin{array}{c}\text { https://cgiarcsi.community/2019/01/24/global-aridity-index-and-poten } \\
\text { tial-evapotranspiration-climate-database-v2/ (Trabucco and Zomer } \\
\text { 2019) }\end{array}$
\end{tabular}

Areas growing major crops such as rice, wheat and maize during kharif, https://mygeohub.org/publications/11/1 (Zhao and Siebert 2015) rabi and zaid season data

Prediction (2025) of monthly precipitation anomalies data (climate change scenario)

https://gisclimatechange.ucar.edu/ (NCAR GIS Program 2012) 


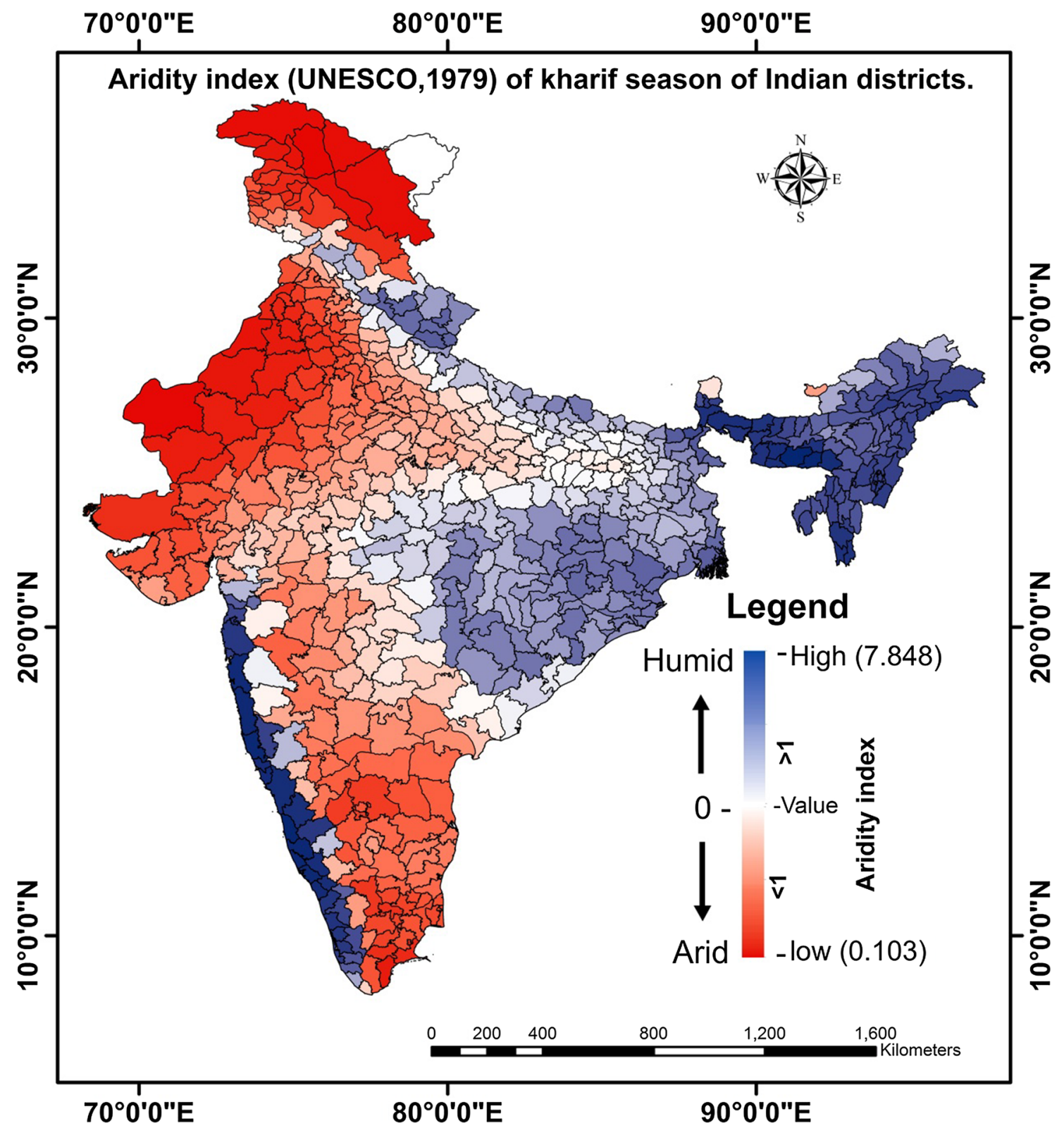

Fig. 1 The AI of kharif season

state). The majority of the area of northeast states district as well as southwest districts of India get adequate precipitation, whereas most of central India and west India remain dry. Birthal et al. (2014) also evaluated long-term rainfall over India during various seasons.

\subsection{Potential Evapotranspiration Pattern Analysis}

Seasonal variability of potential evapotranspiration plays a crucial role in influencing hydrological regime, thus impacting the vegetation dynamics including seasonal agricultural crops' water demand (Liu et al. 2015). The evaluation significantly supports in various applications including irrigation plan and understanding climate change impacts (Lang et al. 2017). The maps were produced for kharif, rabi and zaid seasons utilizing the long-term (1970-2000) PET at the district level of India. The long-term PET pattern in all three seasons is more pronounced and significantly high in arid and semiarid regions of India due to climatic limitations (Tewari et al. 2014). The majority of districts of the state of Rajasthan (such as Jaisalmer, Bikaner, Ganganagar, Barmer, Jodhpur and Churu), Tamil Nadu (such as Ramanathapuram, Thoothukudi and Virudhunagar), Haryana (such as Sirsa, Mahendragarh Hisar) and Punjab (such as Muktsar, Firozpur, Faridkot) retain high PET during kharif season. The PET range during rabi season varies from 112 to 


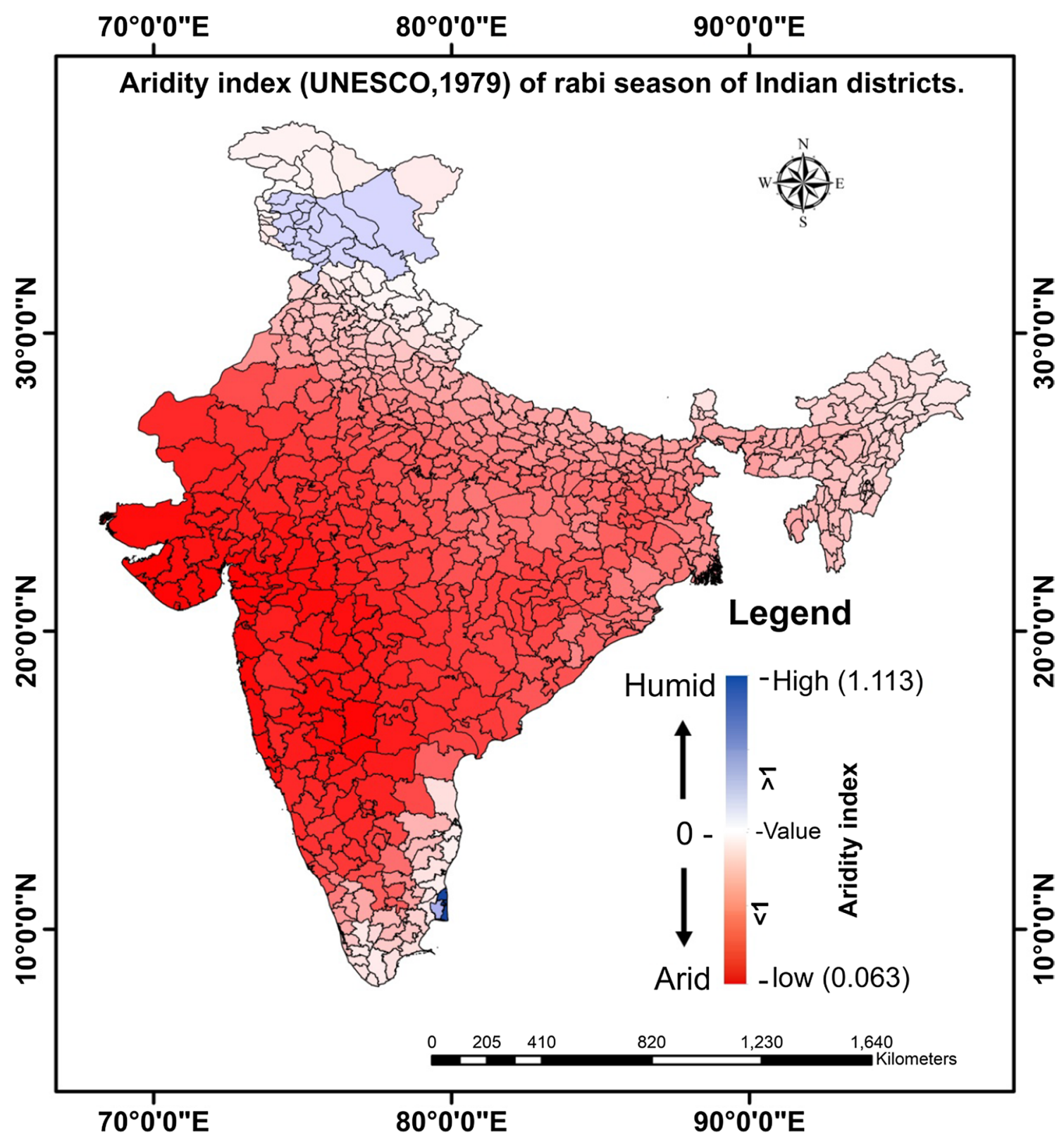

Fig. 2 The AI of rabi season

$693 \mathrm{~mm}$, whereas the highest value was found in the district of Porbandar (Gujarat state). The majority of the south and south-western Indian districts were showing significantly high PET. Similarly, the central and western Indian districts were found with high PET during zaid season.

\subsection{Aridity Index Pattern Analysis}

Crop water requirements are one of the critical issues (FAO 1992), and it can be better judged if the seasonal degree of dryness was analyzed which reflects the crop water needs (http://www.fao.org/docrep/S2022E/s2022e02.htm). There are several formulas given by scientists (Walton 1969; Stadler 2005) to quantify the aridity degree of dryness in the past which have some of their limitations (Maliva and Missimer 2012). In this analysis, the aridity index formula (ratio of precipitation to potential evapotranspiration) given by UNESCO (1979) was adopted which is globally recognized (Maliva and Missimer 2012; Trabucco and Zomer 2019) and supports studies in agriculture sustainability as adaptation to climate change (Zomer et al. 2007, 2008). The AI for the seasons (kharif, rabi and zaid) was evaluated and analyzed the data up to the district level of India. The AI maps of India during kharif, rabi and zaid seasons are given 


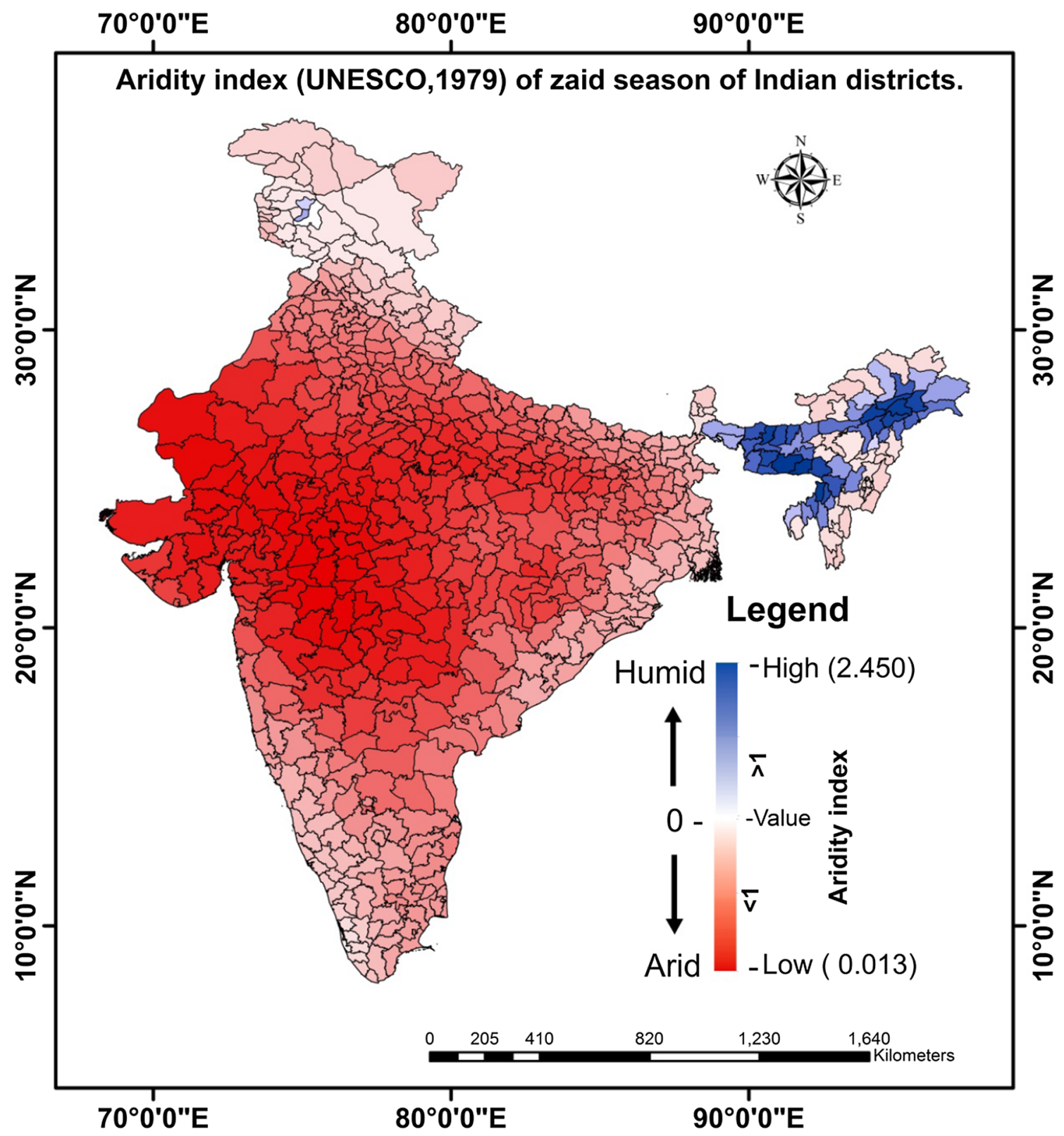

Fig. 3 The AI of zaid season

in Figs. 1, 2 and 3, respectively. In the present study, the critical research gaps have been addressed such as seasonal evaluations of AI at the district level of India.

The higher values of AI reflect more humid condition, and the lowest value for more xeric condition (Zomer et al. 2008). The high-AI districts during kharif season are more significant over the coast of the Western Ghats and northeast regions of India. The medium AI is found in the districts of Orissa, Jharkhand, Chhattisgarh and northern portion of Telangana and Andhra Pradesh states. The majority of districts during rabi season were found with low AI except for few districts such as Karaikal (Puducherry state), Nagapattinam
(Tamil Nadu state) and some districts of the state of Jammu and Kashmir. Similarly, most of the districts during zaid season were found with low AI except few districts of northeast states of India. Similar annual aridity analysis in India has been performed by Ramarao et al. (2018). Furthermore, we have examined several districts of some of the states such as Orissa, Chhattisgarh, Madhya Pradesh and West Bengal receive approximately $>1100 \mathrm{~mm}$ of precipitation during kharif season, whereas these districts significantly were reflected with low aridity index value during rabi (Fig. 2) and zaid seasons (Fig. 3). The water conservation of seasonal (kharif) precipitation at watershed level in such 


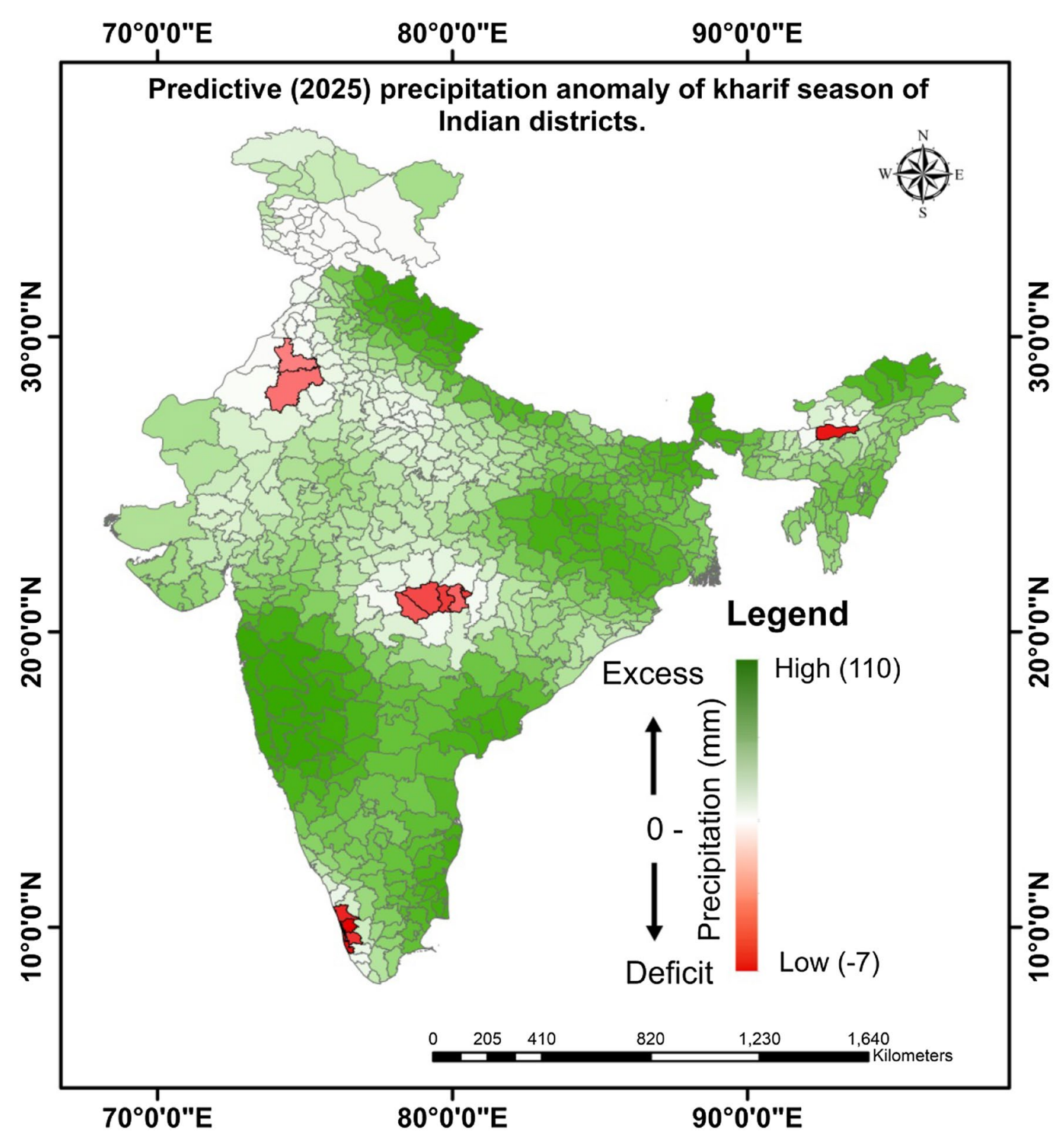

Fig. 4 Predictive precipitation anomaly of kharif season

districts will help significantly and support adequate soil moisture to boost the agriculture crop production up to the next season (Wani et al. 2003). The AI in all seasons in some of the districts such as Anantapur, Cuddapah and Kurnool (Andhra Pradesh state); Mahbubnagar and Nalgonda (Telangana state); Kolar and Bagalkot (Karnataka state); Akola, Bid and Buldana (Maharashtra state); Ashoknagar, Datia, Guna (Madhya Pradesh state) in the arid and semiarid regions was found notably low (Figs. 1, 2, 3), which are major farmer suicide hot spot (Bhushan 2016; Carleton 2017). These districts significantly suffering from poverty (Lewis 2013) need policy intervention to develop a concrete plan (Goparaju and Ahmad 2019) including integrated watershed management strategies with traditional ecological knowledge for long-term sustainable management for climate resilience (James et al. 2018).

\subsection{Predictive (2025) Precipitation Pattern Analysis}

The future seasonal precipitation pattern is important because it gives the idea to predict the drought risks/soil moisture deficit which is significant to make an adaptation strategy and mitigation planning for dry-land agriculture, especially in semiarid regions (Jodha et al. 2012). The future (2025) precipitation anomaly (climate change scenario, RCP 


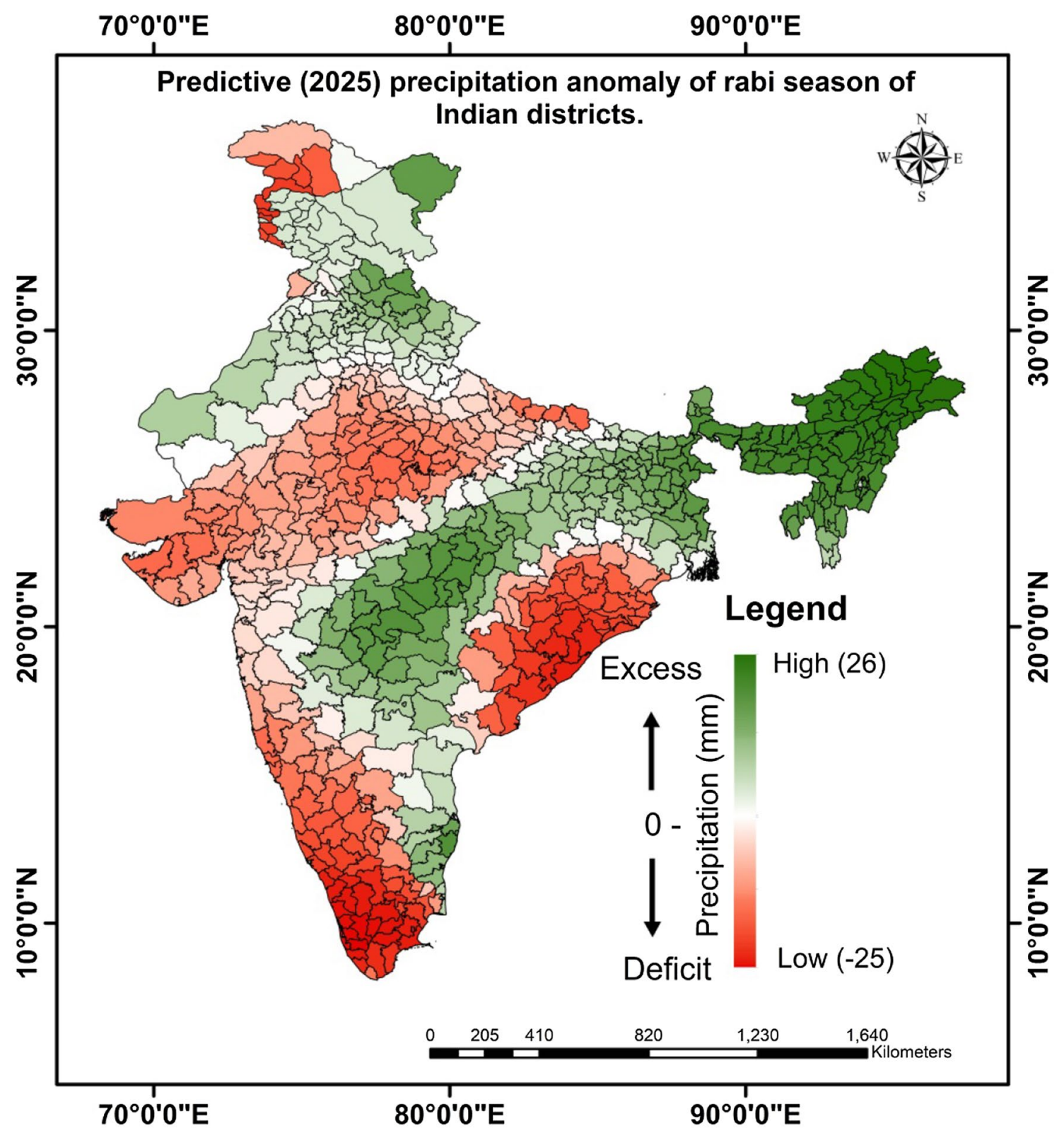

Fig. 5 Predictive precipitation anomaly of rabi season

4.5: Inman 2011) maps during kharif, rabi and zaid seasons of districts of India are given in Figs. 4, 5 and 6, respectively.

The future precipitation deficit for the year 2025 in kharif season was found in 11 districts (Ernakulam, Alappuzha, Thrissur and Kottayam: Kerala state; Sonitpur: Assam state; Bhandara, Nagpur, Wardha and Gondiya: Maharashtra state; Churu and Hanumangarh: Rajasthan state) of India. Similarly, in the year 2025, approximately $45 \%$ of the district (equivalent to 345 districts) of India will face precipitation deficit during rabi season. The highest 15 districts with precipitation deficit during the rabi season for the same base year were found to be in the state of Kerala and Tamil Nadu (Fig. 5). The significant precipitation deficit in the year 2025 was observed in the districts of the state of Orissa during the same base season which is one of the major povertydominated states (Bhandari and Chakraborty 2015). In the zaid season for the year 2025, the precipitation variation was found to be very notable over India and precipitation deficit was found to be significant in the districts of Jammu and Kashmir, Uttaranchal, Kerala and Madhya Pradesh states of India.

\subsection{Major Crops Area Analysis}

Climate change impact on agriculture production will be more vital in the future and creates major challenges to the 


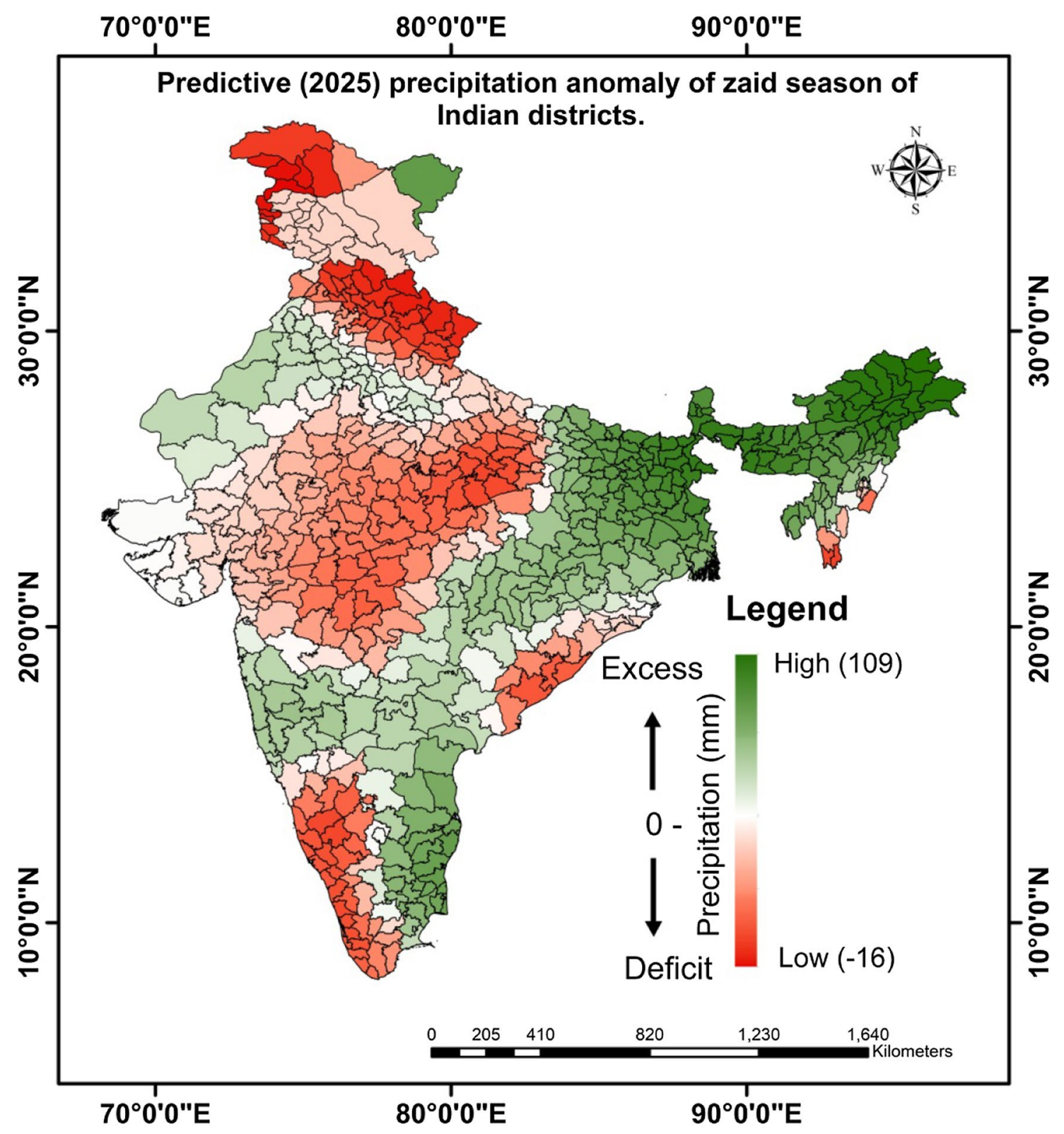

Fig. 6 Predictive precipitation anomaly of zaid season

livelihoods, food security and nutrition availability of a large number of people (IPCC 2014). There are significant proofs of the negative yield of major crops in several regions of India due to rising temperature/ water stress and reduction/ depletion in the number of rainy days (Venkateswarlu and Rao 2013). The situation further aggravates when the country receives insignificant seasonal rainfall which impacts the district-level food production. The future prediction of food demand by the end of 2050 should be increased at least by $70 \%$ to meet the demand of future population (FAO 2010). Here, we have analyzed the data for the year 2005 of major food crops such as rice, wheat and maize at the district level of India for better comprehension. The rice crop areas during kharif season were found to be the highest in five districts (Moga, Patiala, Sangrur, Amritsar and Ludhiana) of the state of Punjab of India. Similarly, the rice area during rabi season was more pronounced in the districts of West Bengal, Bihar and Orissa. The zaid rice areas were very significant in the districts of West Bengal, Orissa and southern states of India. The rice crop areas during all three seasons are found highest in six districts of the state of West Bengal. The majority of the districts of West Bengal state were used for rice cultivation for more than one season because of the high land suitable for agro-ecological zones (Adhikari et al. 2011). Wheat is a rabi crop that is grown in the winter season which needs cool winters for seed germination/early 
growth and hot weather for crop maturity (Mahajan 2012; FAO 2012). The district crop areas for wheat were found to be the highest in the states of Punjab, Haryana and Uttar Pradesh. The highest crop area (more than 75\%) was found in the districts of Moga (Punjab state), Sangrur (Punjab state), Kaithal (Haryana state), Mansa (Punjab state) and Muktsar (Punjab state). These states' lands area are significantly suitable for wheat because it is climatically suitable, fertile and well supported by irrigation facility (Kumar et al. 2014). Maize is the third most important cereal crop in India after rice and wheat (Khatkar et al. 2016), which is grown significantly in kharif and zaid seasons (Zhao and Siebert 2015). The maize crop areas during kharif season were found to be the highest in the districts of Haveri (Karnataka state) followed by Panch Mahals (Gujarat state), Banswara (Rajasthan state), Kannauj (Uttar Pradesh state) and Hamirpur (Himachal Pradesh state). Similarly, during zaid season the maize crop areas were found to be the highest in the districts of Khagaria (33\%), Begusarai (30\%), Madhepura (21\%) and Saharsa (19\%) of Bihar state of India (Zhao and Siebert 2015). The evaluation of maize crop area (>25\%) in all seasons was found highest in five districts of India. They are Khagaria (Bihar state), Haveri (Karnataka state), Panch Mahals (Gujarat state), Begusarai (Bihar state) and Banswara (Rajasthan state).

\section{Conclusion}

In the present study, we have used remote sensing datasets such as seasonal long-term precipitation, potential evapotranspiration and future 2025 precipitation anomaly pattern at the district level of India. Furthermore, we have computed the seasonal AI utilizing the formula given by UNESCO to address one of the critical research gaps at the district level of India. Such an attempt will significantly support when combined with other district-level ancillary datasets to support for livelihood improvements and climate change adaptations programs, especially in arid and semiarid regions (Tewari et al. 2014). The long-term seasonal AI is important because it gives the circa estimates about the need for the water demand of the majority of seasonal crops. In our study, we found several districts of some of the states of India receiving adequate precipitation during kharif season and manifested with low aridity index in rabi and zaid seasons. These districts with low AI highlight the need to modify/increase the existing irrigation system toward adequate rainwater conservation (seasonal rain) at the watershed level (Sharma 2009) with appropriate technologies (http://www.fao.org/3/w7314e/w7314 e0q.htm). Such measures will enhance the soil moisture to support the existing/future crop water requirement which will significantly boost agriculture production in the long run. The study of future (2025) prediction of precipitation deficits during kharif season was found noticeable in some of the districts of states of Kerala and Assam which are known for rice production (Karunakaran 2014; Ahmed et al. 2011). Furthermore, precipitation deficit for the year 2025 during rabi and zaid seasons is very prominent at the district level of India. Additionally, we have evaluated some of the major crops such as rice, wheat and maize at the district level of India. The result showed that rice crop areas were very significant in the district of West Bengal because of the crop suitability to the agro-ecological zone. Wheat crop area was found highest in the districts of the states of Punjab, Haryana and Uttar Pradesh because the majority of districts in these areas are found climatically suitable, fertile and well supported by irrigation facility (Kumar et al. 2014). The overall evaluation of the present work manifests the need of synergic approaches/strategies to mitigate the climate change impact as a long-term goal to obtain sustainability in food security, enhancing the livelihood and magnifying the farm household for future (Goparaju and Ahmad 2019). Harnessing the potentiality of remote sensing data with GIS analysis has the enormous capability and will support significantly when integrated with in situ ancillary datasets to address the farmer's problems faster, better and at a greater scale.

Acknowledgements The authors are grateful to the WorldClim-Global Climate Data, CGIAR Geospatial Community of Practice/Consortium for Spatial Information (CGIAR-CSI), MyGeoHub, NCAR's GIS Program Climate Change Scenarios GIS and DIVA GIS for providing free download of various datasets used in the analysis.

\section{Compliance with Ethical Standards}

Conflict of interest The authors declare that they have no conflict of interests.

Open Access With the author(s)' decision to opt for Open Choice the copyright of the article changed in December 2019 to () The Author(s) 2019 and the article is forthwith distributed under the terms of the Creative Commons Attribution 4.0 International License (http://creativecommons.org/licenses/by/4.0/), which permits use, sharing, adaptation, distribution and reproduction in any medium or format, as long as you give appropriate credit to the original.

\section{References}

Adhikari B, Bag MK, Bhowmick MK, Kundu C (2011) Status paper on rice in West Bengal. In: Rice knowledge management portal (RKMP). Directorate of Rice Research, Rajendranagar, Hyderabad

Ahmad F, Goparaju L, Qayum A (2019) Geo-spatial perspective of vegetation health evaluation and climate change scenario in India. Spat Inf Res. https://doi.org/10.1007/s41324-018-00231-3

Ahmed T, Chetia SK, Chowdhury R, Ali S (2011) Status paper on rice in Assam. In: Rice knowledge management portal. Directorate of rice research, Hyderabad: Rice State Wise, pp 1-49

Anwar MR, Liu LD, Macadam I, Kelly G (2012) Adapting agriculture to climate change: a review. Theor Appl Climatol 113(1-2):225245. https://doi.org/10.1007/s00704-012-0780-1 
Asfaw S, McCarthy N, Lipper L et al (2016) What determines farmers' adaptive capacity? Empirical evidence from Malawi. Food Secur 8:643. https://doi.org/10.1007/s12571-016-0571-0

Ashaolu ED, Iroye KA (2018) Rainfall and potential evapotranspiration patterns and their effects on climatic water balance in the Western Lithoral Hydrological Zone of Nigeria. Ruhuna J Sci 9(2):92-116. https://doi.org/10.4038/rjs.v9i2.45

Bhandari L, Chakraborty M (2015) Spatial poverty across India. https ://www.livemint.com/Home-Page/BH4Yupc3zGc2gs067s6eKN/ Spatial-poverty-across-India.html. Accessed 18 Feb 2019

Bhushan S (2016) Details of farmers suicides from 2010 to 2014 (From :Ministry of Agriculture \& Farmers Welfare). https://data.gov.in/ resources/details-farmers-suicides-2010-2014-ministry-agricultur e-farmers-welfare. Accessed 20 Nov 2018

Birthal P, Tajuddin KM, Negi D, Agarwal S (2014) Impact of climate change on yields of major food crops in india: implications for food security. Agric Econ Res Rev 27:145. https://doi. org/10.5958/0974-0279.2014.00019.6

Carleton TA (2017) Crop-damaging temperatures increase suicide rates in India. PNAS 114(33):8746-8751. https://doi. org/10.1073/pnas.1701354114

FAO (1992) Crop water requirements. http://www.fao.org/docre p/018/s8376e/s8376e.pdf. Accessed 18 Feb 2019

FAO (2010) "Climate-Smart" agriculture policies, practices and financing for food security, adaptation and mitigation. Food and Agriculture Organization of the United State of America (FAO): Rome, Italy, 2010; pp 1-49. http://www.fao.org/docre p/013/i1881e/i1881e00.htm. Accessed 20 Nov 2018

FAO (2012) Herbaceous crops http://www.fao.org/3/i2800e/i2800 e07.pdf. Accessed 18 Feb 2019

Fick SE, Hijmans RJ (2017) Worldclim 2: new 1-km spatial resolution climate surfaces for global land areas. Int J Climatol. https ://doi.org/10.1002/joc.5086

Goparaju L, Ahmad F (2019) Analyzing the risk related to climate change attributes and their impact, a step towards climate-smart village (CSV): a geospatial approach to bring geoponics sustainability in India. Spat Inf Res. Accepted for publication

Guhathakurta P, Rajeevan M (2008) Trends in the rainfall pattern over India. Int J Climatol 28:1453-1469

Haworth BT, Biggs E, Duncan J, Wales N, Boruff B, Bruce E (2018) Geographic information and communication technologies for supporting smallholder agriculture and climate resilience. Climate 6(4):97. https://doi.org/10.3390/cli6040097

Iizumi T, Ramankutty N (2015) How do weather and climate influence cropping area and intensity? Glob Food Secur 4:46-50. https://doi.org/10.1016/j.gfs.2014.11.003

Inman M (2011) Opening the future. Nat Clim Change 1:7-9. https ://doi.org/10.1038/nclimate 1058

IPCC (2014) Climate change 2014: synthesis report. contribution of working groups I, II and III to the fifth assessment report of the intergovernmental panel on climate change. In: Pachauri RK, Meyer LA (eds) Core writing team, IPCC, Geneva

Jagannathan P, Bhalme HN (1973) Changes in pattern of distribution of southwest monsoon rainfall over India associated with sunspots. Mon Weather Rev 101:691-700

James AJ, Bahadur AV, Verma S (2018) Climate resilient water management: an operational framework from South Asia. ACT Learning Paper

Jimenez D, Ramirez-Villegas J (2018) Unlocking big data's potential to strengthen farmers' resilience: the platform for big data in agriculture. In: Ospina AV (ed) Big data for resilience storybook: experiences integrating big data into resilience programming. International Institute for Sustainable Development, Winnipeg, pp 97-108

Jodha NS, Singh NP, Bantilan MCS (2012) Enhancing farmers' adaptation to climate change in arid and semi-arid agriculture of india: evidences from indigenous practices: developing international public goods from development-oriented projects. Working Paper Series no. 32. Patancheru 502 324, Andhra Pradesh, India: International Crops Research Institute for the Semi-Arid Tropics

Karunakaran N (2014) Paddy cultivation in Kerala: trends, determinants and effects on food security. Artha J Soc Sci 13(4):21-35. https://doi.org/10.12724/ajss.31.2

Khatkar B, Chaudhary N, Dangi P (2016) Production and consumption of grains in India. https://doi.org/10.1016/b978-0-08-10059 6-5.00044-5

Killeen TJ, Solorzano LA (2008) Conservation strategies to mitigate impacts from climate change in Amazonia. Philos Trans R Soc Lond B Biol Sci 363(1498):1881-1888. https://doi.org/10.1098/ rstb.2007.0018

Kumar A, Poswal R, Singh G et al (2014) Wheat Cultivation in India (Pocket Guide). https://www.researchgate.net/publication/32232 9607_Wheat_Cultivation_in_India_Pocket_Guide

Lang D, Zheng J, Shi J, Liao F, Ma X, Wang W, Chen X, Zhang M (2017) A comparative study of potential evapotranspiration estimation by eight methods with FAO Penman-Monteith method in southwestern China. Water 9:734. https://doi.org/10.3390/w9100 734

Lewis MW (2013) Remapping poverty in India. http://www.geocu rrents.info/geonotes/remapping-poverty-in-india. Accessed 22 Jan 2019

Liu Y, Ren L, Yang X et al (2015) Effects of precipitation and potential evaporation on actual evapotranspiration over the Laohahe basin, northern China. Proc IAHS 371:173-179. https://doi.org/10.5194/ piahs-371-173-2015

Mahajan AKR (2012) Monitoring growth of wheat crop using digital image processing. Int J Comput Appl 50(10):18-22

Maliva R, Missimer T (2012) Arid lands water evaluation and management. Environ Sci Eng. https://doi.org/10.1007/978-3-642-29104 $-3 \_2$

Mooley DA, Parthasarathy B (1983) Variability of the Indian summer monsoon and tropical circulation features. Mon Weather Rev 111:967-968

Mooley DA, Parthasarathy B (1984) Fluctuations in all-India summer monsoon rainfall during 1871-1978. Clim Change 6:287-301. https://doi.org/10.1007/BF00142477

NCAR GIS Program (2012) Climate change scenarios, version 2.0. Community climate system model, June 2004 version 3.0. http:// www.cesm.ucar.edu/models/ccsm3.0/ was used to derive data products. NCAR/UCAR. https://gisclimatechange.ucar.edu/ Accessed 5 Jan 2019

Parthasarathy B, Munot AA, Kothawale DR (1994) All-India monthly and seasonal rainfall series: 1871-1993. Theor Appl Climatol 49:217. https://doi.org/10.1007/BF00867461

Rajeevan M, Unnikrishnan CK, Jyoti B, Niranjan K, Sreekala P (2012) Northeast monsoon over India: variability and prediction. Meteorol Appl 19(2):226-236. https://doi.org/10.1002/met.1322

Ramarao MVS, Sanjay J, Krishnan R et al (2018) On observed aridity changes over the semiarid regions of India in a warming climate. Theor Appl Climatol. https://doi.org/10.1007/s00704-018-2513-6

Salinger MJ, Sivakumar MVK, Motha R (2005) Reducing vulnerability of agriculture and forestry to climate variability and change: workshop summary and recommendations. Clim Change 70(12):341-362. https://doi.org/10.1007/1-4020-4166-7_18

Sharma S (2009) Rethinking watershed development in India: strategy for the twenty first century. In: Achouri M, Tennyson K, Upadhyay $\mathrm{K}$, White $\mathrm{R}$ (eds) Proceedings of asian regional workshop on water management, preparing for next generation watershed development programs and projects. Food and Agriculture Organization, Rome, 11-13 September 2003 
Spinoni J, Vogt J, Barbosa P (2015) European degree-day climatologies and trends for the period 1951-2011. Int J Climatol 35(1):25-36. https://doi.org/10.1002/joc.3959

Srinivasa Rao Ch, Gopinath KA, Prasad JVNS, Kumar P, Singh AK (2016) Climate resilient villages for sustainable food security in tropical India: concept, process, technologies, institutions, and impact. Adv Agron 140:101-214. https://doi.org/10.1016/ bs.agron.2016.06.003

Stadler SJ (2005) Aridity indexes. In: Oliver JE (ed) Encyclopedia of world climatology. Springer, Heidelberg, pp 89-94

Stefan S, Zhao G (2014) Mapping of rainfed and irrigated agriculture in India-data inventory and documentation. Technical report, GEOSHARE pilot-crop science bonn. https://mygeohub.org/ publications/11/serve/1/17

Tewari J, Ram M, Roy M, Dagar JC (2014) Livelihood improvements and climate change adaptations through agroforestry in hot arid environments. In: Dagar J, Singh A, Arunachalam A (eds) Agroforestry systems in India: livelihood security and ecosystem services. Advances in Agroforestry, vol 10. Springer, New Delhi. https://doi.org/10.1007/978-81-322-1662-9_6

Thornthwaite CW (1948) An approach toward a rational classification of climate. Geogr Rev 38:55-95

Trabucco A, Zomer R (2019) Global aridity index and potential evapotranspiration (ET0) climate database v2. figshare. Fileset. https:// doi.org/10.6084/m9.figshare.7504448.v3
UNESCO (1979) Map of the world distribution of arid regions: explanatory note, vol 22. UNESCO, Paris. ISBN: 92-3-101484-6

Venkateswarlu B, Rao VUM (2013) Climate change and its impact on Indian agriculture. Clim Change Model Mitig Adapt https://doi. org/10.1061/9780784412718.ch15

Walton K (1969) The arid zone. Aldine Publishing Co, Chicago, IL

Wani SP, Pathak P, Sreedevi TK, Singh HP, Singh P, (2003) Efficient management of rainwater for increased crop productivity and groundwater recharge in Asia. IWMI Books, Reports H032643, International Water Management Institute

Zhao G, Siebert S (2015) Season-wise irrigated and rainfed crop areas for India around year 2005. MyGeoHUB. https://doi.org/10.13019 $/ \mathrm{m} 2 \mathrm{cc} 71$

Zomer RJ, Bossio DA, Trabucco A, Yuanjie L, Gupta DC, Singh VP (2007) Trees and water: smallholder agroforestry on irrigated lands in Northern India. International Water Management Institute, Colombo, (IWMI Research Report 122)

Zomer RJ, Trabucco A, Bossio DA, Verchot LV (2008) Climate change mitigation: a spatial analysis of global land suitability for clean development mechanism afforestation and reforestation. Agric Ecosyst Environ 126(1-2):67-80. https://doi.org/10.1016/j. agee.2008.01.014 